UDC 37.014.6:005.642.4

DOI 10.31494/2412-9208-2020-1-2-21-29

\title{
CULTURAL AND EDUCATIONAL ACTIVITY OF M. O. KORF IN THE LIGHT OF DEVELOPMENT OF MONITORING OF QUALITY OF EDUCATION
}

\section{КУЛЬТУРНО-ОСВІТНЯ ДІЯЛЬНІСТЬ М. О. КОРФА У СВІТЛІ РОЗВИТКУ МОНІТОРИНГУ ЯКОСТІ ОСВІТИ}

\author{
Yuliia VASEIKO, \\ Юлія ВАСЕЙКО, \\ Candidate of Philological Sciences, \\ Associate Professor \\ jvaseyko@gmail.com \\ https://0000-0001-5227-1097 \\ Lesia Ukrainka East European Східноєвропейський національний \\ National University \\ 13, Volya Av., Lutsk, \\ 43021 \\ Liliya YAROSHCHUK, \\ університет імені Лесі Українки \\ $\triangle$ проспект Волі, 13, м. Луцьк, \\ 43021 \\ Лілія ЯРОЩУК, \\ Candidate of Pedagogical Sciences, кандидат педагогічних наук, доцент \\ Ph.D, Associate Professor \\ lilia_y77@ukr.net \\ https://0000-0002-4862-5590

$\begin{array}{cc}\text { Berdiansk State Pedagogical } & \text { Бердянський державний } \\ \text { University } & \text { педагогічний університет } \\ \triangle 4 \text {, Schmidt St., Berdiansk, } & \triangle \text { м. Бердянськ, вул. Шмідта, } 4 \\ \text { Zaporizhzhia region, } 71100 & \text { Запорізька обл., 71100 }\end{array}$ \\ Original manuscript received: June 22, 2020 \\ Revised manuscript accepted: August 19, 2020
}

\begin{abstract}
The aim of the research is to discover the pedagogical and cultural ideas of baron M. O. Korf and their impact on the modern monitoring of quality of education. The pedagogical ideas of baron $\mathrm{M}$. O. Korf refering to the problem of monitoring of quality of education are exposed in the article. In fact he was the first person in Ukraine and Russia who started verification of knowledge of peasants and students. The research methodology is based on the principles of historicism, system-formation, scientific character, verification, the author's objectivity, moderated narrative constructivism, and the use of general scientific (analysis, synthesis, generalization) and specially pedagogical (empiric, historical comparative) methods. The scientific novelty of the article consists in the fact that for the first time in history of pedagogics it was found out on the basis of works of Mykola Korf and publications of researchers of his inheritance that a teacher tested the knowledge of peasants and students of elementary school and then made a report. A question for conversation was divided into two categories: those which analytically name an object and offer child to define the sign and the ones that enumerate signs synthetically, not naming an object, and offer to thinking of child to recreate an object according to its signs. Nowadays there is the idea that the founder of the world monitoring of quality of education is the American association of Progressive Education Association in the of United States. However, we prove that Mykola Korf ICV 2018: 77.58


measured the quality of knowledge of students, conducted monitoring of quality of knowledge, considerably before associations. Conclusions the results of research allow to assert that the pedagogical ideas of baron M. O. Korf can be considered as basic developments of modern theory and practices of monitoring of quality of education because he organized the research before American association of Progressive Education Association in the of United States.

Key words: monitoring, knowledge, methodology, conversation, pedagogical ideas.

The basis of scientific problem consists of the opening of pedagogical ideas of baron M. O. Korf, reffering to the problem of monitoring of quality of education. In fact he was the first person in Ukraine and Russia who started verification of knowledge of peasants and students.

The purpose of our secret research is the studying of the pedagogical ideas of M. Korf and their influence on the modern monitoring of quality of education.

Research results. This concept does not have exact, unambigiuous interpretation, as it is used in the different spheres of research and scientific and practical activity of human.

"Monitoring" (from English "control", "watching") - it is both research form and method of providing the sphere of management with high-quality information (Kuhar, 2010).

In pedagogical literature a term «monitoring» is used in a meaning of watching the effectiveness of educational process (monitoring educational achievement of students); sometimes the term is understood as the ordinary pedagogical control (monitoring of success of students in the particular subject); more often it is used for the studying of certain parameters by the educational system or its separate elements or subjects of educational process (monitoring of quality of preparation of specialists on certain speciality, monitoring of logistics support of educational establishments, state of health of students etc.). Therefore monitoring has the research status, but not empirical collection of information about certain characteristics and properties of the educational system.

Monitoring today became the independent direction of administrative activity in education in which the integration of measuring, researches, experiment, informatics and management passes take place (Borovkova, T. I., \& Morev, I. A., 2004).

The monitoring system has gained complex, integral character. In the general understanding monitoring can be defined as a permanent watching of certain process in order to expose its accordance to the desirable result or initial state.

Professor Lashenko O. I. asserts that monitoring in education is a tool of evaluation, thanks to which the conclusions and judgements which are formulated in relation to the quantitative and quality indexes of development of the investigated object appear. That is why there are peculiar signs of the technological process, procedures and methodologies, characteristic for different methods collections where the processing of data and distribution of information works. According to the technological aspect, monitoring is similar to 
sociological research, however has more wide spectrum of characteristic tasks and facilities. Testing is the one we have to emphasize (Lyashenko, 2007).

Let us find out history of the formation of monitoring in education. T. Lukina asserts that it is divided into four stages.

First stage: the years $30-50$ s of the 20th century. Progressive Education Association of United States by means of the monitoring investigated the level of preparation of graduating students 30 at schools, their highly emotional lines (social position and critical thinking).

Second stage: the years 60 - 70s the International Education Association started the international comparative monitoring educational research.

Third stage: the years 80 - 90s the problems of determination of profitability, organization of effective management, evaluation of the productivity of providing of the educational systems with resources become relevant. Quality of education turns into political category international comparative monitoring researches in the field of education.

Fourth stage: from the years 90 s of the 20th century to nowadays. This stage is marked with an orientation on political support and scientific substantiation of researches (Lukina, 2006).

Thus, the monitoring concept begins from the years $30-50$ s of the 20th century in the USA. However, we accede to the researchers of pedagogical heritage of baron M. O. Korf. M. Antoshchak (Antoshhak, 2006), I. Kushnirenko and V. Zhylinskyi (Kushnirenko \& Zhylinskyj, 2011) who assert in the researches that in summer 1880 baron $M$. Korf began new and very important for education business after the return from Geneva. He planned to check (to conduct monitoring!) how strong was education given to the students at new school. According to this purpose he personally conducted examinations in six different villages of the Mariupol and Oleksandriya districts to the adult peasants who completed the course at the first graduation of school, that was 14 years ago.

"It is necessary to go around the area during spring for examination, to poll all students without an exception, in all subjects of studies" (Korf, 1882), advises M. O. Korf to the members of district college council.

In consonance with the methodology of questioning, an examiner should not complicate the answer of children by formulation of questions. «Any question, wrote M. Korf, must be offered clear, simply and to be changed until a student understands an examiner» (Korf, 1882).

The attitude of examiner toward children must be filled with large sense of love. "If you only do not love children, then you will be a not examiner, but anexecutioner, then school is a wrong place for you" (Korf, $\mathrm{N}$. A., 1882). Opinions of M. Korf about the order and methodology of realization of examinations substantially differed from the official system of verification of knowledge of students, that is built on principles of the strict discipline, fear and callous, bureaucratic relations between examiner and the students. In the same time he was very distant from any liberal moods during the knowledge test and demanded the objective approach to every student (Sayapina, 2010). 
Simultaneously with baron Korf, on his request and on his program, the well-known figure of folk education countess P. S. Uwarowa who corresponded with baron for a long time conducted similar experience in a number of schools of Smolensk, Wlodimir and Moscow provinces.

In all five provinces the knowledge was checked in about 500 adult peasants. After that Korf came to the conclusion that "common opinion that our schoolchildren unlearn things that were learned before very soon, must fall silent forever, as the inappropriate for the reality" (Korf, 1883). At Berdyansk province people had a survey. Baron Korf prepared the questions for peasants. The survey was organized with a help of the leader of the nobility K. W. Kowalewskiy.

184 people have been examined, mainly the residents of villages Pokrovka, Voznesenka, Astrakhanka, Andriyivka, Mykolaivka. Peasants who graduated from school not less than two years ago were polled. Verificationquestioning took place this way: peasants got forms with questions, among that there were questionnaire data, arithmetical ask, writing and reading (Antoshhak, 2006).

The best results appeared from reading (an examiner explained it using the voice method of studies by M. Korf), worst - from arithmetics and writing. K. B. Kowalewski made conclusion : "...spending on school issues will be justified if peasants after graduating from folk school during a few winters have the opportunity to repeat things that have already been studied, fill up the knowledge with a help of reading books" (Sbornyk, 1910). The results of survey were sent to Office and M. O. Korf. About 500 adult peasants were polled in all (Antoshhak, 2006).

The gained on the basis of objective observation results gave an opportunity to find out that in course of time ability and skills were partly lost by peasants. Peasants who studied only during one winter became almost illiterate until the verification time. Only those who were engaged in a selfeducation, saved skills of reading and writing. The peasants who had been taught by teachers who adhered the terms of correct teaching process had better knowledge (El'nickij, 1903). M. O. Korf came to the conclusion that adult peasants who finished the Korf 3 years course need to be given the opportunity of repeating, deepening the gained knowledge and skills.

As M. L. Peskowski stated : "The baron Korf hot propaganda of the refresh of the adult peasants elementary cognition level has overcome the same propaganda in the Scandinavian states for a few years" (Peskovskyj, 1893).

As a member of district college council $\mathrm{M}$. O. Korf conducted the verification examinations, determining the quality of studies of schoolchildren. "Verification test, - he wrote, - is a holiday for children, that they expect not only without any timidity but also with the greatest delight and impatience... We enter the Vremievskaya school: all children stand up and merrily pronounce "hello", that was long-time custom of this establishment that welcomes every peasant entering the school ... For peasants, attending the Vremievskaya school the special bench was put in order «to listen how do the guys study. 
When we enter the school we see every of 63 students who have in advance unlined paper for writing work during examination in advance; asp boards and books for reading are put 0 on student's desks by the hall monitors in advance as well, then less time is wasted on distribution of manuals... Neither for writing nor for verbal answers I give them no marks, except the compositions of higher class... The whole verification test is conducted by me so all the forms were continuously busy, due to what all the children were happy and an examiner had time to check everything without the superfluous fatigue of children" (Korf, 1872). The idea of M. Korf was being developed on the pages of magazines. In October, 1881 his article of "The educational level adult peasants" appears in the magazine "Ruskaya mysl". Here an author gives a report on verification of districts. In the same month "Vestnik Europy" prints the report by M. Korf on the state of folk education in the Berdiansk district, where an author calls to the idea of necessity of verification of knowledge of peasants again (Sbornyk, 1910).

Let us try to consider how a baron M. Korf checked up knowledge first of peasants, and later of students of the elementary school. In a report he wrote: it would lead to nothing if, for example, a teacher, repeating exercises of the "Native word", would tell the student: Name a few animals or the names of valuable metals. To be limited to the similar questions means to study only by heart, and a teacher must influence on thinking. Aiming to improve the work of teachers, offers the compilated standards of questions for the revision of the past lessons of the "Native word" (Peskovskyj, 1893).

M. Korf suggests to check quality of knowledge of students in a form conversation M. He divides questions for conversation into two categories:

1) those who analytically name an object and offer to the child to define a sign :

Question. What are you dressed in

Answer. In coat.

Question. What is a coat?

Answer. Dress.

Question. What is it made of?

Answer. Of the skin of sheep.

Question. What is the skin of sheep?

Answer. Part of sheep.

Question. What is sheep?

Answer. Domestic, four-footed, herbivore.

Question. Why do you name it a domestic animal?

Answer. It lives at home.

Question. No, it spends almost the whole year in steppe. Why is it nevertheless domestic?

Answer. A sheep is hand, in winter lives at home, it is useful

Question. Why do you name a sheep a four-footed animal?

Answer. because of its 4 feet.

If a sheep broke one leg, or one leg was chopped off from her then how many feet would it have? 
Answer. 3.

Question. How can you call a sheep in this case considering the amount of feet?

Answer. Four-footed.

Question. But sheep has 3 feet, not 4.

Answer. It borns with 4 feet, and that is why it is named four-footed.

Question. Why do you name a sheep the herbivore animal?...;

2) those who enumerate signs synthetically, not naming an object, and offer a child to think how to recreate an object by its signs, : do I mean?

Question. An animal flies midair without a feather but with wings: What

Answer. Insect.

Question. What trees that have the same named fruit do you know ?

Answer. Pear, plum, cherry (Ushynskyj,1989).

In the reprinted edition "Our tiny friend",by the founder I. F. Shumilova, such examples of questions are set for verification of knowledge.

Question. What can be melt?

Answer. Glass, sand, copper, gold, silver, tin, flint, salt, different minerals (Korf, 2010).

Question. Who destroys the rodents?

Answer. Cat, ferret, grass-snake, viper (Korf, 2010).

Question. Who destroys insects?

Answer. Spider, hen, duck (Korf, 2010).

Question. Who conveys a man?

Answer. Horse, bullock, donkey, deer, dog, ostrich, camel, elephant (Korf, 2010).

Question. Destroy animals that harm the plants

Answer: a) midair in the day-time: birds;

b) midair at night: bats;

c) on the ground in the day-time: frogs, birds, foxes;

d) on the ground at night: ferret, frog, hedgehog, owl;

e) on trees: birds;

f) underground: mole (Korf, 2010).

Question. Is the caterpillar useful?

Answer. Silkworm (Korf, 2010).

Question. Harmful insects.

Answer. Fly, flea, bedbug, lice, cockroach, may-bug, panary beetle, locusts, horse-fly (Korf, 2010).

As we see, from examples, they remind present test tasks.

Except it, M. O. Korf tried to provide schools with creative teachers. he conducted interesting events to that end: personally took (mainly from rural young people) away the people who were interested in getting knowledge and increasing the level of self-development ,who were prone to pedagogical activity and prepared them to the posts of teachers at elementary schools. M. O. Korf checked up the level of their knowledge. Those who passed examinations successfully, were given certifications and the right to teach at 
elementary schools and Korf arranged them to work.

Then he kept touch with them. Two times a year in autumn, at the beginning of school year, and in spring, at the end of school year he went to schools, visited lessons, precisely analysed them, checked up the knowledge of students, gave the practical advice about the increase of level and quality of conducting lesson, conducted model lessons, arranged teaching conventions (Vitvic'ka, \& Berezjuk, \& Osadcha, 2005).

Conclusions. Results of the research allow to assert that the fundamental pedagogical ideas of baron $\mathrm{M}$. O. Korf can be considered as the developments of modern theory and practice of monitoring of quality of education, in fact he conducted monitoring of knowledge in the 20th century, that means considerably before than the American association of education (Progressive Education Association in the of United State).

\section{Література}

Антощак М. М. Недільні повторювальні школи М. О. Корфа. Наукові пращі Історичного факультету Запорізького Державного Університету. Вип. XIX. Запоріжжя, 2006. С. 113-119.

Боровкова Т. И., Морев И. А. Мониторинг развития системы образования. Часть 1. Теоретические аспекты. Владивосток: Изд-во Дальневосточного университета, 2004. $150 \mathrm{c}$.

Вітвицька С. С., Березюк О. С., Осадча 3. А. Дидактичні погляди видатних українських педагогів (друга половина XIX перша половина XX століття). Житомир: Вид-во ЖДУ, 2005. 190 с.

Ельницкий К. В. Барон Николай Александрович Корф (к 20-летию со дня смерти). Воронеж, 1903. С. 14-16.

Корф М. О. Наш друг. Малютка / упор. І. Ф. Шумілова. Запоріжжя: Просвіта, 2010. $18+256+115+8+38 \mathrm{c}$.

Корф Н. А. Первые воскресне повторительные школы. Русская мысль. 1882. № VIII. C. $81-84$.

Корф Н. А. Русская начальная школа. Руководство для земских гласных и учителей сельских школ. СПб.: Изд. Д. Е. Кожанчикова, 1872. 274 с.

Кухар Л. О. Теоретичні аспекти освітнього моніторингу. Науковий часопис національного педагогічного університету імені М. П. Драгоманова. Серія № 5 . Педагогічні науки: реалії та перспективи. Вип. 22: зб. наук. пр. Київ: Вид-во НПУ імені М. П. Драгоманова, 2010. С. 229.

Кушніренко І. К., Жилінський В. І. М. О. Корф: справа всього життя. Запоріжжя: Дніпропетровський металург, 2011. 300 с. $128 \mathrm{c}$.

Лукіна Т. Моніторинг якості освіти: теорія і практика. Київ: Шкіл. світ, 2006.

Ляшенко О. І. Організаційно-методичні засади оцінювання якості освіти. Академія педагогічних наук України. Київ: Педагогічна думка, 2007. С. 128-134.

Отчет Александровского уездного училищного совета о состоянии народного образования в уезде за 1882-1883 года / авт. текста Н. Корф. Александровск, 1883. 284 с.

Песковский М. Л. Барон Н. А. Корф, его жизнь и общественная деятельность. СПб, 1893.95 с.

Саяпіна С. А. Погляди М. Корфа щодо організації навчального процесу в земській школі (друга половина XIXст.). Збірник наукових праць Бердянського 
державного педагогічного університету. Бердянськ: БДПУ, 2010. № 4. С. 209215.

Сборник Постановлений Бердянского Уездного земского собрания с 1866 по 1908 год. М., 1910. С. 469-471.

Ушинский К. Д. Педагогические сочинения: в 6 т. Т. 4 / сост. С. Ф. Егоров. Москва: Педагогика, 1989. 528 с.

\section{References}

Antoshhak, M. M. (2006). Nedilni povtoryuvalni shkoly M. O. Korfa. Naukovi praci Istorychnoho fakultetu Zaporizkoho Derzhavnoho universytetu. Vyp. XIX. Zaporizhzhya. 113-119 [in Ukrainian].

Borovkova, T. I., \& Morev I. A. (2004). Monitoring razvitija sistemy obrazovanija. Chast' 1. Teoreticheskie aspekty. Vladivostok [in Russian].

Vitvic'ka, S. S., \& Berezjuk, O. S., \& Osadcha, Z. A. (2005). Didaktichni pogljadi vidatnih ukraïns'kih pedagogiv (druga polovina XIX persha polovina XX stolittja). Zhitomir [in Ukrainian].

El'nickij, K. V. (1903). Baron Nikolaj Aleksandrovich Korf (k 20-letiju so dnja smerti). Voronezh [in Russian].

Korf, M. O. (2010). Nash drug. Maljutka / (Ed.) I. F. Shumilova. Zaporizhzhja: Prosvita [in Ukrainian].

Korf, N. A. (Ed.). (1883). Otchet Aleksandrovskoho uezdnoho uchylyshhnoho soveta o sostoyanyy narodnoho obrazovanyya $v$ uezde za 1882-1883 hoda. Aleksandrovsk, 1883 [in Russian].

Korf, N. A. (1882). Pervye voskresne povtoritel'nye shkoly. Russkaja mysl'. VIII [in Russian].

Korf, N. A. (1872). Russkaja nachal'naja shkola. Rukovodstvo dlja zemskih glasnyh i uchitelej sel'skih shkol. SPb: Izd. D. E. Kozhanchikova. [in Russian].

Kuhar, L. O. (2010). Teoretychni aspekty osvitn"oho monitorynhu. Naukovyj chasopys nacionalnoho pedahohichnoho universytetu imeni M. P. Drahomanova. Seriya № 5. Pedahohichni nauky: realiyi ta perspektyvy. Vypusk 22 zb. Kyiv: NPU imeni M. P. Drahomanova. 229 [in Ukrainian].

Kushnirenko, I. K, \& Zhylinskyj, V. I. (2011). M. O. Korf: sprava vsoho zhyttya. Zaporizhzhya: Dnipropetrovskyj metalurh. 300 s. [in Ukrainian].

Lukina, T. (2006). Monitorynh yakosti osvity: teoriya i praktyka. Kyyiv: Shkilnyj svit [in Ukrainian].

Lyashenko, O. I. (2007). Orhanizacijno-metodychni zasady ocinyuvannya yakosti osvity. Akademiya pedahohichnyx nauk Ukrayiny. Kyyiv: Pedahohichna dumka, 128-134. [in Ukrainian].

Peskovskyj, M. L. (1893). Baron, N. A. Korf, eho zhyzn y obshhestvennaya deyatelnost. SPb [in Russian].

Sayapina, S. A. (2010). Pohlyady M. Korfa shhodo orhanizaciyi navchalnoho procesu v zemskij shkoli (druha polovyna XIX st.). Zbirnyk naukovyx prac Berdyanskoho derzhavnoho pedahohichnoho universytetu (Pedahohichni nauky). Berdyansk: BDPU, № 4. 209-215 [in Ukrainian].

Sbornyk Postanovlenyj Berdyanskoho Uezdnoho zemskoho sobranyya s 1866 po 1908 hod. Moskva. (1910). 469-471 [in Russian].

Ushynskyj, K. D. (1989). Pedahohycheskye sochynenyya: v 6 t. T. 4. Moskva: Pedahohyka [in Russian]. 


\section{АНОТАЦІЯ}

Мета дослідження - розкрити педагогічні ідеї Миколи Корфра та їх вплив на сучасний моніторинг якості освіти. У статті досліджено педагогічні ідеї барона М. О. Корфра, що стосуються проблеми моніторингу якості освіти, адже він перший в Україні та Росії започаткував перевірку знань селян та учнів. Методологія дослідження спирається на принципи історизму, системності, науковості, авторської об'єктивності, поміркованого наративного конструктивізму, а також на використання загальнонаукових (аналіз, синтез, узагальнення) та спеціально педагогічних (емпіричні, порівняльно-історичні) методів. Наукова новизна полягає в тому, що вперше в історії педагогіки на основі праць Миколи Коррра та публікацій дослідників його спадщини з'ясовано, що педагог у формі бесіди перевіряв знання спочатку селян, а пізніше й учнів початкової школи, про що звітував. Питання для бесіди поділяв на дві категорії: $m i$, які аналітично називають предмет і пропонують дитині визначити його ознаку і ті, які синтетично перераховують ознаки, не називаючи предмета, $i$ пропонують мисленню дитини відтворити предмет за його ознаками. Нині у світі побутує думка, що засновником світового моніторингу якості освіти $\epsilon$ Американська асоціація поступної освіти (Progressive Education Association in the United State). Проте ми доводимо, що Микола Корфь вимірював якість знань учнів, тобто проводив моніторинг якості знань, значно раніше асоціації.

Результати проведеного дослідження дозволяють стверджувати, що педагогічні ідеї барона М. О. Корфра можна вважати підгрунтям розробки сучасної теорії та практики моніторингу якості освіти, адже він проводив моніторинг знань ще в XIX cm., тобто значно раніше за Американську асоціацію поступної освimu (Progressive Education Association in the United States).

Ключові слова: моніторина, знання, методика, бесіда, педагогічні ідеї. 